\title{
Flipped Classroom Teaching Optimization of College English under Blending Learning Theory
}

\author{
Li Meijing \\ Foreign Language Department \\ Jilin Business and Technology College \\ Changchun, China \\ 182076127@qq.com
}

\begin{abstract}
Flipped classroom is one of the hottest topics of education reform and innovation at home and abroad. Through introducing flipped classroom teaching mode, this paper, applies specific teaching cases and carries out a research on the optimization of college English teaching under blending learning theory, hoping to inspire college English classroom teaching based on blending learning.
\end{abstract}

Keywords-Flipped classroom; college English teaching; blending learning

\section{INTRODUCTION}

In recent years, the Flipped Class Model proposed by Jonathan Bergmann and Aaron Sams comes to gradual emergence and becomes one of the hottest topics of education reform and innovation at home and abroad. As a new classroom teaching mode, Flipped Class Model makes up for the weakness of traditional classroom teaching that college students must absorb knowledge synchronously in the classroom and teachers fail to consider various levels of students which causes students to absorb and understand knowledge differently. In flipped classroom, students must first complete knowledge learning at home and participate in cooperative learning at school, thus, classroom becomes an interaction place between students and students.

Blending learning is the combination of Face to Face classroom learning and E-learning. Professor He Kekang believed blending teaching mode combines the advantages of traditional teaching and network teaching methods, not only playing a role of teachers to guide, inspire and monitor students' learning in the teaching process, but also fully embodying students' initiative, enthusiasm and creativity as the main body of learning[1]. The core idea of blending learning is the adoption of different ways to solve the problem according to the requirements of the different problems and the application of different information transfer modes to solve the problem, for the purpose of achieving maximum benefit at minimum cost [2].

According to the National Medium and Long-term Plan for Education Reform and Development, it is obviously seen that Flipped Class Model has important significance and extensive use in college English teaching. This paper, under the guidance of blending learning theory, carries out a preliminary research on the application and optimization of Flipped Class Model in college English classroom teaching in order to not only ensure teachers' leading role but also fully reflect students' main body status in flipped classroom.

\section{TheOreticAl Basis OF The Research}

\section{A. The limitations of traditional teaching}

In the 17th century, the Czech educator Comenius issued a book named Didactica Magna, advocating teacher-centered education idea in traditional teaching process. Centuries later, the traditional teaching idea is still rooted in the field of education. However, with the improvement of education goals and requirements, traditional teaching can no longer meet the needs teaching. Some scholars put that the students' learning process can be divided into two parts: information transmission and internalization absorption. In classroom teaching, teachers see to information transmission, imparting knowledge to students and students finish the homework after class and internalize knowledge. Traditional classroom teaching only pays attention to the knowledge transmission but ignores the guidance of internalization absorption to students. It is clear that traditional teaching itself has some limitations.

First of all, it fails to teach student in accordance of their aptitude. The contradiction between group teaching and individual differences condemns it a flawed method to impart knowledge in the classroom. Secondly, theory outweighs practice. Traditional teaching mode focuses on teaching experience instead of students' real experience, failing to achieve ideal learning effect; Third, rationality outweighs sensibility. Traditional classroom gives priority to teacher lectures and students' ability of rational thinking and problem solving, which can lead to extreme pursuit of abstract theory and concept and is not conducive to students' mastery of knowledge. Education psychology research shows that the students' mastery of knowledge is a process of combining perceptual knowledge and rational knowledge. The lack of either of them will cause students to grasp the concept, formula and principle difficultly; Fourth, result outweighs process. In traditional teaching, teachers tend to tidy up the problem solving steps and directly tell students, although it saves time, indirect experience does not promote students' understanding and exercise students' ability of independent thinking, which is bad for students' intelligence and personality development in the long run. 


\section{B. Flipped Class Model}

Flipped Class Model, also known as flipped classroom, is an instructional strategy and a type of blended learning that reverses the traditional learning environment by delivering instructional content, often online, outside of the classroom. It moves activities, including those that may have traditionally been considered homework, into the classroom. In a flipped classroom, students watch online lectures, collaborate in online discussions, or carry out research at home and engage in concepts in the classroom with the guidance of a mentor.

Lage, Platt and Treglia's article Inverting the Classroom: A Gateway to Creating an Inclusive Learning Environment in 2000 firstly researched on flipped classrooms at the college level, focusing on two college economics courses and conforming that flipped classroom meets the needs of students with a wide variety of learning styles[3]. Salman Khan became synonymous with the flipped classroom in 2004 and recorded video lesson as one form of the flipped classroom strategy[4][5].The Wisconsin Collaboratory for Enhanced Learning has built two centers to focus on flipped and blended learning. The classroom structure houses technology and collaboration-friendly learning spaces, and emphasis for those involved in the program is placed on individualized learning through non-traditional teaching strategies such as flipped classroom[6].

In practice, Woodland Park High School chemistry teachers Jonathan Bergmann and Aaron Sams became driving forces in flipped teaching at the high school level when, in 2007, they recorded their lectures and posted them online in order to accommodate students who missed their classes. Bergmann and Sams note that one person cannot be credited with having invented the inverted or flipped classroom. Furthermore, they assert that there is no one 'right' way to flip a classroom as approaches and teaching styles are diverse, as are needs of schools [7].

\section{Blending learning}

Blended learning is a formal education program in which a student learns at least in part through delivery of content and instruction via digital and online media with some element of student control over time, place, path, or pace. While students still attend "brick-and-mortar" schools with a teacher present, face-to-face classroom methods are combined with computermediated activities. Blended learning is also used in professional development and training settings.

Online learning gives full consideration to the students' learning style and learning habit and enables students to arrange study time and place independently and even choose learning resources such as auxiliary materials flexibly, fully reflecting personalized learning. Face-to-Face teaching enables the teacher to understand the situation of students' learning and understanding in a timely manner and arrange teaching methods and teaching schedule reasonably according to their aptitude. Therefore, both E-learning and Face-to-Face teaching modes are provided with advantages and disadvantages. And blended learning combines the advantages of both and integrates Face-to-Face classroom teaching and E-learning in order to achieve lower costs and improve the efficiency of learning.

\section{The OptimizATION OF COLLEGE ENGLISH FLIPPED CLASSROOM TEACHING BASED ON BLENDING LEARNING}

Flipped classroom teaching of college English based on blending learning, with the aid of modern education technology, provides students with micro-video before class so that students can participate in the interactive activities, such as: problem solving, discussion and debate, etc. This teaching mode can achieve a win-win effect among teachers and students. On the one hand, students can arrange time flexibly, set the pace for online learning and have more opportunities to participate in group interaction in face-to-face classroom learning, changing passive learning into active learning. On the other hand, teachers can put more energy to monitor students' performance and provides immediate feedback for person or group. Here, in the case of the text A Friend in Need in Book 4 Unit 5 in the new edition of College English, the optimization strategies of flipped classroom teaching based on blending learning are analyzed.

\section{A. Teaching content}

The article is about a hypocritical kindly old man killed a young man who asked him for help. The article uses the writing style of contrast and irony, at the beginning of the text, a lot of words are used to describe the kind characteristic of the hero, but at the end of text, the story shows that a person's appearance is not reliable and the bad guys will have a good disguise. The gist is the text is that appearance is always deceptive.

\section{B. Learner analysis}

Students in the sophomore, after two years of college English learning, have certain English application abilities, and most of them have passed CET4. At the same time, they have certain information processing ability and know how to use network resources to support their own learning. All the students are active, think independently and learn collaboratively.

\section{Teaching objects}

The teaching objects of the text A Friend in Need is presented in Table 1.

TABLE I. TEACHING OBJECTS In AsPeCts of KNOWLEDGE, ABILITy AND EMOTION

\begin{tabular}{|c|l|}
\hline Objects & \multicolumn{1}{|c|}{ Requirements } \\
\hline Knowledge & $\begin{array}{l}\text { Learn how to use useful words and expressions, } \\
\text { definite, in accordance with, instinct, transparent, go } \\
\text { broken, drive at, turn up, current, etc. }\end{array}$ \\
\hline Ability & $\begin{array}{l}\text { Learn to express with these useful words and } \\
\text { expressions in real life; describe a person in English; } \\
\text { search information through extensive reading and } \\
\text { present information in appropriate form, solve problems } \\
\text { through group coordinative learning. }\end{array}$ \\
\hline Emotion & $\begin{array}{l}\text { Know that it is wrongful to judge people solely by their } \\
\text { appearance and at the same time realize there must be } \\
\text { one as dangerous as Edward Burton in real life }\end{array}$ \\
\hline
\end{tabular}




\section{Teaching concept}

College English teaching class duration is limited where the teachers often feel it hard to use Flipped Class Model based on blending learning to make an organic combination of extracurricular and in-class learning. Therefore, teachers can let the students master the teaching content with the aid of microvideo and related resources before class at first, and then conduct personalized learning in their guidance in class time, fully embodying the learners-centered personalized learning and teaching.

\section{E. Teaching procedures}

\section{1) Preparation before class}

According to the analysis of the learners and the teaching objects, teachers can first make multiple micro-videos with the following content included: the background knowledge of the text; introduction to the author and his representative works; the text theme and organizational structure; useful words and expressions including definite, in accordance with, instinct, transparent, go broken, drive at, turn up, current, etc.; difficult sentences explanation: Here if ever was a man all of piece. Micro videos are made with Camtasia Studio. At the same time, teachers also need to prepare related practical exercise and reference materials, and the electronic data is uploaded to the college students' English teaching platform. Students login teaching platform to participate in autonomous learning, watching the video and finishing the exercise. Then, they can record problems difficult to solve at the same time and communicate with peers or teachers in the flipped classroom.

2) In-class learning

This paper divides the in-class learning process into three periods and lists them in Table 2.

TABLE II. THE THREE PERIODS OF IN-CLASS LEARNING

\begin{tabular}{|l|l|}
\hline Periods & \multicolumn{1}{c|}{ Tasks } \\
\hline Period & $\begin{array}{l}\text { Teachers ask the content provided to the students before class and } \\
\text { determine whether students have completed the self-study tasks. } \\
\text { Then, some students put forward the problems they encountered in } \\
\text { the self-study and the rest of the students solve these problems } \\
\text { first. If there is no answer to the problems, they are directed by } \\
\text { teachers in detail. }\end{array}$ \\
\hline $\begin{array}{l}\text { Period } \\
2\end{array}$ & $\begin{array}{l}\text { Students are required to discuss certain topic set by the teachers in } \\
\text { groups, such as "Should we judge a person by his/her } \\
\text { appearance?" and the leader of each group summarizes and } \\
\text { presents the discussion result to the whole class. }\end{array}$ \\
\hline
\end{tabular}

3) After-class consolidation

After class, teachers provide relevant information for students and let students write a composition about 800 words to describe one of the students in class and complete the relevant practice at the back of the text.

\section{F. Learning effect evaluation}

Flipped classroom teaching of college English based on blending learning applies the combined method of formative assessment and summative assessment to evaluate students' learning effect. The content of formative assessment includes: online practice completion, the quantity and quality of answers to questions in class, the contribution of group cooperative learning, etc. Teachers take each of the groups as a unit to establish electronic archives for students and make a summative evaluation of the final test for the students.

\section{SugGestions to Optimize the FlipPED ClassRoOM TEACHING OF COLLEGE ENGLISH}

College English learning is different from middle school learning, and it is not suitable to use the interpretation of cramming education mode. On the contrary, college students should give priority to self-study and get inspired in the atmosphere of extracurricular teaching. Flipped Class Model is completely in line with the teaching idea, at the same time, it also can provide specific operational strategies to implement the idea, which has a good application prospect in college English teaching (Wang Xiaodong, 2013)[8]. Flipped Class Model brings new prospects for college English classroom teaching, however, college English teachers should pay attention to the following aspects in order to make Flipped Class Model succeed:

\section{A. Inspire the self-study initiative of learners before class}

Whether Flipped Class Model can achieve a successful face-to-face interaction depends on the learner's preparation for their class activities. However, not all the students are willing to learn the micro-video lessons and related resources before class, which leads to their chances of participation in the classroom activity reducing. Aiming at this problem, teachers can set small test related to the content, and students are required to present the difficult problems they encounter in the process of learning and launch online discussion to solve these problems.

\section{B. Provide clear guidance}

At first, college students may not accept this new model of learning which requires them to spend a lot of time to complete the task before class, so the teacher must provide clear guidance, so that they can successfully complete the whole learning process. Teachers can create the task-based teaching environment and give clear guidance to solve the problem in the process of learning.

\section{Create learning community}

Learning community can provide learners with an information platform sharing their thought, thus, it is very important for teachers to create a collaborative learning community for students. In the community, students can communicate with each other to solve problems, which can not only improve their collaborative learning ability, but also make them form a strong sense of belonging to the team and be willing to accept this new type of classroom learning model.

\section{Provide instant personalized feedback}

The advantage of Flipped Class Model based on blending learning is that it can meet different levels of learners for personalized learning. In the process of learning, learners' progress determines the different degree they master the knowledge. Teachers should set different demands for students in various levels of learning and make a personalized instant 
feedback to learners' questions, so as to keep learners' learning motivation.

\section{CONCLUSION}

The research in this paper finds that flipped class model based on blending learning can to a certain extent improve the learning enthusiasm and classroom participation of college students and is beneficial to the improvement of students' autonomous learning ability, practical ability, problem analysis and solving ability, etc. On the whole, this research has achieved good results. The essence of flipped classroom teaching doesn't lie in its application of information technology, but in the innovation of thinking mode. Certainly, there isn't a perfect teaching mode suitable for all situations in the world. As for the Flipped Class Model, how to design with a better play to its advantages and avoid its disadvantages and how to implement it to make it more adaptable to the teaching status quo of our country still need us to do more research and exploration work in practice in the future.

\section{REFERENCES}

[1] He Kekang. The new development of educational technology theory from blending learning [J] E-education Research, 2004(3)(4):1-6

[2] Li Kedong, Zhao Jianhua. The principle and application mode of blended learning[J] E-education Research, 2004(8):1-6

[3] Maureen Lage, Glenn Platt and Michael Treglia. Inverting the Classroom: A Gateway to Creating an Inclusive Learning Environment[J] Journal of Economic Education, 2000

[4] Clive Thompson, How is Khan Academy Changing the Rules of Education[M], Wired, 2011

[5] Sams, Aaron. The Flipped Class: Shedding Light on the Confusion, Critique and Hype[J]. The Daily Riff. 2011

[6] Wisconsin Collaboratory for Enhanced Learning[J].Wiscel, 2015

[7] Jonathan Bergmann, Aaron Sams. Flip your classroom: reach every student in every class every day [J]. Washington, DC: International Society for Technology in Education, 2011

[8] Wang Xiaodong, Zhang Chenjing. The application research on Flipped Class Model in college teaching[J]Modern Educational Technology, 2013 